\title{
THE IMPORTANCE OF MICROSTRUCTURE OF THE MIDDLE EAR IN OTOSURGERY
}

\section{ZNAČAJ MIKROSTRUKTURE UVA U OTOHIRURGIJI}

Dragoslava Đerić1, ${ }^{2}$, Nenad Arsović ${ }^{1,2}$, Srbislav Blažic ${ }^{2}$

\section{Summary}

The purpose of this paper is to review important anatomical variations and relations in the middle ear that may occur on the human temporal bones. We presented findings of specimens that demonstrated morphological variations involved: the facial nerve canal, an internal carotid artery and upper jugular bulb and pointed out their clinical and surgical importance. The studies were performed on the large collection of the temporal bones (2000 temporal bone specimens) in our laboratory for anatomical and surgical examinations, over the period of many years. In our study the facial nerve dehiscence was commonly present just above the oval window, in about $65 \%$ of the specimens. The middle ear cavity is closely related to the internal carotid artery, which extends medially from the promontory. This part of the wall could be noticed since the carotid channel is always more or less protruded into the lumen of the tube. In some cases (2/150) we noticed a bone defect above the internal carotid artery up to the level of tympanic orifices. In 38 (25.3\%) of the cases, we found that jugular bulb protruded into the cavum tympani, elevating its bottom. The absence of bone wall above the bulb, as well as its dehiscence, could make infection spread from the middle ear spaces more easily, thus possibly causing thrombophlebitis. A highly positioned jugular bulb in the cavum tympani could lead to difficulties in differential diagnosing. In cases with clinical symptoms of jugular foramen mass, it is important to make identification of an expanding process (cholesteatoma, paraganglioma, meningeoma), but also the presence of vascular anomalies. CT scan of the temporal bone, performed before any ear surgery, is the main modality for identification of such anomalies and preventing possible insults.

Key word: anatomical variations, middle ear, otosurgery.

\section{Sažetak}

Cilj rada je da prikaže značaj anatomskih varijacija i odnosa srednjeg uva koje mogu da se jave na humanim temporalnim kostima. Prikazani su uzorci koji pokazuju morfološke varijacije na kanalu facijalnog živca, unutrašnjoj karotidnoj arteriji, i gornjem jugularnom bulbusu a ukazano je na njihov klinički i hirurški značaj. Studije su vršene na velikoj kolekciji temporalnih kostiju (2000 uzoraka temporalnih kostiju) u našoj laboratoriji za anatomska i hirurška ispitivanja, tokom više godina. U našoj studiji kanal facijalnog živca je često dehiscentan iznad ovalnog otvora, u oko 65\% slučajeva. Srednje uvo je u bliskom odnosu sa unutrašnjom karotidnom arterijom, koja se pruža medijalno od promontoriujuma. Ovaj deo zida se može uočiti kod manje ili veće protruzije u lumen tube. U nekim slučajevima (2/150) otkriven je defekt koštanog zida unutrašnje karotidne arterije u nivou timpanalnog otvora tube. Nađeno je da u 38 (25,3\%) slučajeva, bulbus vene jugularis protrudira u kavum timpani uzdižući pod kavuma. Odsustvo koštanog zida iznad bulbusa, kao i dehiscencije, može da olakša širenje infekcije u prostore srednjeg uva, kao i pojavu tromboflebitisa. Visoko pozicioniran bulbus u kavum timpani stvara teškoće u diferencijalnoj dijagnozi. U slučajevima sa kliničkim simptomima mase jugularnog foramena, veoma je vazno da se identifikuje prošireni proces (holesteatom, paraganglioma, meninegeoma), ali takođe i vaskularne anomalije. CT temporalne kosti, urađen pre otohirurške intervencije, predstavlja osnovni modalitet, za identifikaciju takvih anomalija kao i prevenciju eventualnog incidenta.

Ključne reči: anatomske varijacije, srednje uvo, otohirurgija.

\section{INTRODUCTION}

Having precise knowledge of anatomical variations and relations of the middle ear is very important for middle ear surgery to be safely performed and to improve its outcome. Success of an operation depends on identifying anatomical structures and relations in the operative filed, but also on avoiding a potential surgical accident. The goals of temporal bone surgery depend on various factors such as: types of disease, surgical procedure, diagnostic methods, morphological factors, surgical experiences and others.
A new concept in otosurgery has been developed on the basis of anatomical studies with implications of different biomechanical methods. With advancement of microscope in the ear surgery, there is a renewed interest amongst otologists to study the microscopic anatomy. Background of microstructure and knowledge of various biomechanical aspects have had an influence on introducing many novel procedures in treating otologic diseases. 
The purpose of this paper is to review important anatomical variations and relations in the middle ear that may occur on the human temporal bones. We presented findings of specimens that demonstrated morphological variations involved: the facial nerve canal, an internal carotid artery and upper jugular bulb and pointed out their clinical and surgical importance.

\section{MATERIALS AND METHOD}

The studies were performed on a large collection of temporal bones (2000 temporal bone specimens) in our laboratory for anatomical and surgical examinations, over the period of many years. From the collection we selected specimens with microscopic variations that might be significant in otosurgery. Methods used were anatomi$\mathrm{cal}$ and histological, and analyses were performed using a microscope. The temporal bone were harvested from cadavers and prepared by the standard method (fixed in $10 \%$ buffered formalin for 4 weeks, than decalcified in $5 \%$ nitric acid for 3 days, and finally rinsed with distilled water). The specimens were sectioned in different planes (frontal, horizontal, sagittal) and analyzed under operative microscope. Morphological variations were examined on various sections depending on anatomical structures. Significant findings were photographed.

\section{RESULTS}

\section{FACIAL CANAL DEHISCENCE}

The facial nerve is the most vulnerable structure in the middle ear during otologic surgery. In practice, we commonly performed tympano - mastoid surgery when treating middle ear diseases, and we have to keep in mind that occurrence of facial paralysis as a postoperative complication, may be a devastating consequence of surgery. Also, the appearance of facial palsy may have a considerable psychological impact owing to social isolation and serious problems. Because of this, having knowledge of surgical anatomy of the facial nerve is essential in middle ear surgery. An otologist who is inadequately familiar with the facial nerve usually has a tendency to do incomplete surgery or sometimes to avoid it. Preoperative evaluation of morphology, particularly the region of the oval window and the tympanic segment of the fallopian canal is very important for stapes surgery. A useful assessment may be done by CT that allows visualization of numerous anatomical structures.

The facial nerve transverse throughout the temporal bone within its bony canal called the fallopian canal. After leaving the geniculate ganglion, the facial nerve bends posteriorly forming its tympanic segment. The nerve than passes inferiorly bending above the oval window to form the mastoid segment. The second genu is in the area between the oval window niche and pyramidal process where the nerve bends. The tympanomastoid segment of the facial nerve shows variations in course and in its relation with various middle ear structures. Facial nerve dehiscence is a common anatomic variation that usually occurs in the tympanic segment above the oval window, but it is also encountered at the level of the geniculate ganglion and the mastoid segment adjacent to the surrounding pneumatic cells (1-3). Although anatomy of the facial nerve is known, each temporal bone can be surprising and make the otosurgeon face a less frequent or even unseen anomaly. Baxter A (1) reported that in 535 temporal bones in 55\% of the facial nerves were dehiscent. Ninety-one percent were located in the tympanic segment and $9 \%$ in the mastoid segment. Among the cases of dehiscence in the tympanic segment, $83 \%$ were located adjacent to the oval window involving the lateral portions of the canal with the nerve protruding from its canal in $26 \%$. Their diameter ranged from 0.5 to $3.1 \mathrm{~mm}$. Other studies have described similar findings $(4,5)$.

In our studied temporal bones, we found that in $45.5 \%$ of the cases, the upper wall of the oval window niche is formed by the prominence of the facial canal (over the tenth, the prominence partially covers the oval window). The facial nerve dehiscence was commonly present just above the oval window, in about $65 \%$ of the specimens. The area of dehiscence varied between 0.4 and $2.5 \mathrm{~mm}$. In some cases, the lateral wall of the facial canal was very thin with exposition of the nerve trunks. That situation may predispose a prolepsis of the facial nerve trunk over the stapes footplate, and clinically cause a conductive hearing loss or shielding surgical access to the footplate. During the operation, if the surgeon does not pay enough attention to the place where the bony defects are frequently expected, an accidental injury may occur and consequently facial palsy. In that situation, the surgeon should decide as to modify a surgical technique to enhance footplate visualization. Haussler R et al. (6) performed 595 stapedotomies and found 40 cases (6.7\%) where the facial nerve had an abnormal course. In 32 patients the nerve prolapsed over the oval window and in 8 of these, there was a total prolapse of the nerve over the oval window.

In middle ear infection, acute or chronic, the inflammatory process may involve the facial nerve at any point but it most commonly occurs in the tympanic segment. The main reason for this is the exposed facial nerve trunk due to dehiscence. A pathological process as granulation tissue or cholesteatoma is very often localized around the tympanic part of the facial nerve. However, degenerative changes in the facial nerve may be present without clinical impairment of its function. These changes may have a potential for developing facial paralysis during chronic otitis media (7). 


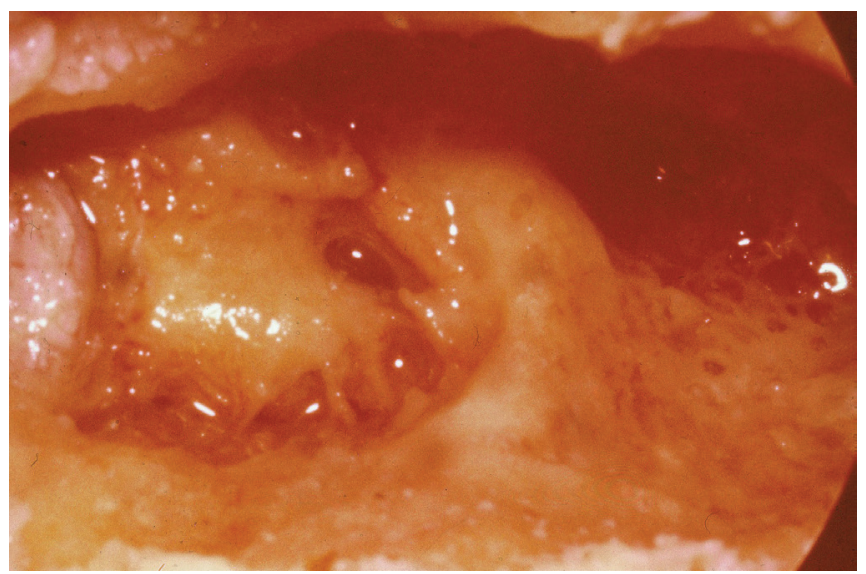

Figure 1. Horizontal section of the temporal bone. The prominence of the facial canal partially covers the oval window. Dehiscence on the internal carotid canal at the level of Eustachian tube.

\section{CAROTID CANAL DEHISCENCE}

The middle ear cavity is closely related to the internal carotid artery, extending medially from the promontory, i.e. it makes the anteromedial part of the inner wall of the Eustachian tube. This part of the wall could be noticed since the carotid channel always more or less protrudes into the lumen of the tube. The prominence is variable and in some cases $(2 / 150)$ we noticed a bone defect above the internal carotid artery up to the level of tympanic orifices. The wall was completely present up to the level of tympanic orifice, but it was absent towards the lumen of the tube, so that the carotid was exposed directly into the lumen. The macroscopic prevalence of carotid canal dehiscence is low (2\%), while the microscopic incidence is about $8 \%$. The occurrence of an exposed artery must be kept in mind whenever a surgical intervention is undertaken in the region of anterior mesotympanum or Eustachian tube. Being familiar with the occurrence of a rare vascular anomaly such as an aberrant internal carotid artery (that internal carotid artery takes in an aberrant lateral course in the temporal bone) is very important in otosurgery. An aberrant internal carotid artery can mimic other middle ear diseases that may result in a misdiagnosis. An otologist should be aware of this potentially life - threatening anomaly because it may be obscured by a pathological process due to chronic otitis or other diseases. The symptoms and signs of aberrant internal carotid artery are often nonspecific and include hearing loss, positive tinnitus, and a retrotympanic mass behind the anterioinferior part of the membrane. It can mimic various pathological lesions, such as glomus tumors, dehiscent jugular bulb, cholesterol granuloma, petrous carotid aneurysms, hemangioma and others (8-10).

A CT scan of the temporal bone, performed before any ear surgery, is the main modality for identifying such anomalies. It is important to prevent a possible insult (aural bleeding and serious consequences which are potentially life threatening) during a surgical procedure.
In the case of chronic middle ear infection or to reduce tinnitus, however, a surgical treatment is indicated, including covering the aberrant vessel with bone and soft tissues or trimming the handle that touches the exposed carotid artery. Therefore, the benefit of the surgery must be debated against the risk of possible consecutive neurological disorders and serious bleeding complications.

\section{A High JUgular bulb AND DEHISCENCE}

The middle ear cavity is closely related to the upper bulb of the internal jugular vein that lies under the hypotomanic base. A variable anatomy of the jugular bulb is not rare and is usually manifested as a high jugular or dehiscent bony wall. A high jugular bulb refers to a superior location of the bulb that brings it into contact with structure in the hypotympanum and mesotympanum. Often a high jugular bulb is incidentally found on otoscopic examination. Clinically, blush discoloration at the poster inferior quadrant of the tympanic membrane may raise the suspicion of a high jugular bulb. If the bulb extends laterally to the tympanic membrane, clinically, it may cause positive tinnitus or conductive hearing loss, whereas when extending more medially, sensorineural hearing loss or vertigo may be present. The frequency of a high jugular bulb varies between $6 \%$ and $34 \%(11,12)$.

In our studied cases, there were $38(25.3 \%)$ of the 150 temporal bones $(25,3 \%)$, where jugular bulb protruded into the cavum tympani, elevating its bottom. This prominence could be pronounced as follows: in 10 out of 38 (26.3\%) samples, in which we determined that the bulbuls protruded into the cavum tympani, bulbus' prominence was slightly pronounced, situated only in the medial portion of the hypotympanum, not expanding the level of the lower annulus tympanucus. In other 25 cases $(65,9 \%)$ the bulbuls' prominence extended above the lower annulus tympanicus, reaching the stylomastoid prominence while in 3 out of $38(7,8 \%)$ cases the bulb had a high position, thus filling the hypotympanum and closing the lower half of the round window niche.

In cases of prominent bulbus, the thickness of the bone wall that separates it from the cavum tympani is 1.2 $\mathrm{mm}$, on average, ranging to $3,5 \mathrm{~mm}$. Usually, this wall thickness ranges from 1 to $2 \mathrm{~mm}$, is rarely of paper consistency and even more rarely $2.5-3.5 \mathrm{~mm}$, and in 2 cases the bone wall was entirely absent. In 2 out of 38 cases with prominent bulbus, the bone wall was absent. A highly positioned jugular bulb in the cavum tympani could lead to difficulties in differential diagnosing glomus jugular tumors. An exact diagnosis is sometimes made not later than ear exploration.

These anatomical variations are considered important for middle ear surgery for many reasons. They are usually recognized by the appearance of heavy hemorrhage 


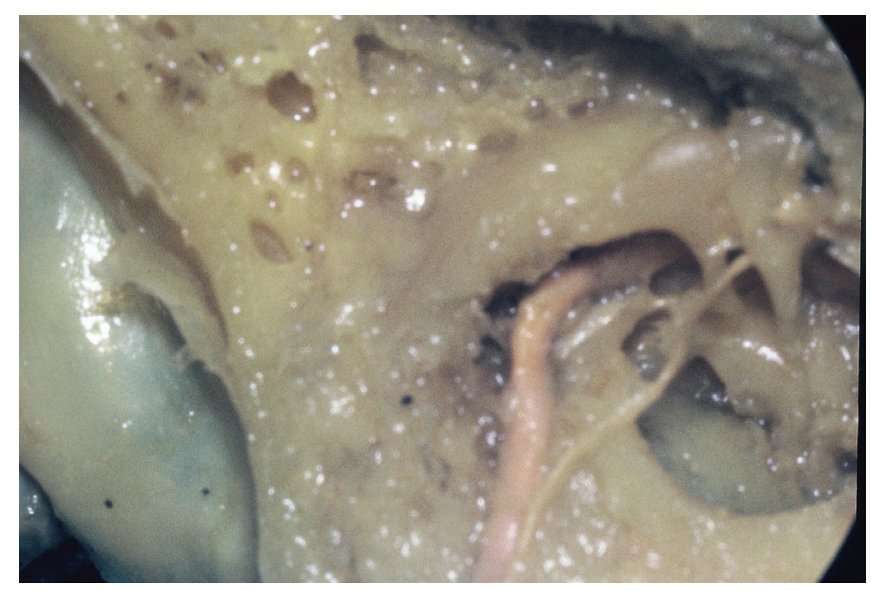

Figure 2. Horizontal section of the temporal bone. A high position of the jugular bulb and dehiscence of bone wall

during surgery in this area. Huang R. et al. (11) reported that dehiscent high jugular bulb was proven in 10 out of 1657 patients who underwent surgical interventions for middle ear cleft disease. The absence of bone wall above the bulb, as well as its dehiscence, could make infection spreading from the middle ear spaces easier, thus possibly causing thrombophlebitis. A highly positioned jugular bulb in the cavum tympani could lead to difficulties in differential diagnosing glomus jugular tumor. In cases with clinical symptoms of jugular foramen mass, it is important to make identification of an expanding process (cholesteatoma, paraganglioma, meningioma), but also presence of vascular anomalies, such as enlarged jugular bulb or aberrant internal carotid artery.

\section{NAPOMENA:}

Rad je usmeno izložen na mini simpozijumu povodom 90 godina Klinike za otorinolaringologiju i maksilofacijalnu hirurgiju - Savremena shvatanja u mikrohirurgiju uva na 43. simpozijumu Stremljenja i novine u medicini, Medicinski fakultet u Beogradu, 10.12.2014.

\section{References}

1. Baxter A.: Dehiscence of the Fallopian canal: an anatomical study. J Laryngolol Otol 1971, 85:587-594

2. Aslan A., Mutlu C., Celik O., Govsa F.: Surgical implications of anatomical landmarks on the lateral surface of the mastoid bone. Surg radiol Anat. 204, 26:263-267

3. Maru N., Cheita A., Mogoanta A., Prejoianu B.: Intratemporal course of the facial nerve:morphological, topographic and morphometric features.Rom J Morphol Embryol. 2010, 51:243-248

4. Takahashi H., Sando I.: Facial canal dehiscence. Ann Otol Rhinol, 1992, 101:925-930

5. Nilssen E., Wormald P.: Facial nerve palsy in mastoid surgery. J Laryngol Otol 1997, 11:113-116

6. Ballester M., Blaser B., Hausler R.: Stapedotomy and anatomical variations of the facial nerve. Rev Laryngol Otol Rhinol 2000, 121:181-186

7. Djeric D.: Neuropathy of the facial nerve in chronic otitis media without associated facial paralysis. Eur Arch Otorhinolaryngol 1990, 247:232-236 